\title{
Parents' experiences of caring for a child with a cleft lip and/or palate: a review of the literature
}

\author{
P. Nelson, ${ }^{\star}$ A.-M. Glenny, $\dagger$ S. Kirk $\ddagger$ and A.-L. Caress \\ *School of Community Based Medicine, University of Manchester \\ $\uparrow$ School of Dentistry, University of Manchester, and \\ $\ddagger$ School of Nursing, Midwifery and Social Work, University of Manchester, Manchester, UK \\ Accepted for publication 20 March 2011
}

\section{Keywords}

cleft lip, cleft palate, parents' experiences, parents' perceptions

Correspondence: Pauline Nelson, School of Community Based Medicine, University of Manchester, Oxford Road, Manchester M13 9PL, UK E-mail: pauline.nelson@ manchester.ac.uk

\begin{abstract}
This review brings together for the first time the existing quantitative and qualitative research evidence about the experiences of parents caring for a child with a cleft. It summarizes salient themes on the emotional, social and service-related experiences of parents and critiques the literature to date, comparing it with wider, selected literature from the field of children's long-term conditions, including disability. The review suggests that there are similarities and differences between the literatures, in terms of research focus and approach. Similarities are found across children's conditions in the perspectives of parents on emotional, social and service-related aspects, although much of the cleft literature is focused on the early stages of children's lives. However, the quality of cleft research to date about parents' experiences has also been variable, with a narrow emphasis on cross-sectional, deficit-orientated psychological approaches focused mainly on mothers. Despite a substantial literature, little qualitative research has examined parents' perspectives in-depth, particularly about their child's treatment journey. This contrasts with the wider children's literature, which has traditionally drawn not only on psychological approaches but also on the broader perspectives of sociology, social policy, nursing and health services research, using both qualitative and quantitative methods, often in integrated ways. Such approaches have been able to highlight a greater range of experiences from both mothers and fathers, about caring for a child with a long-term condition and views about treatment. The review identifies a lack of comparable research in the cleft field to examine parents' experiences and needs at different stages of their children's lives. Above all, research is needed to investigate how both mothers and fathers might experience the long-term and complex treatment journey as children become older and to elicit their views about decision making for cleft treatments, particularly elective surgeries.
\end{abstract}

\section{Introduction}

Clefts of the lip and/or palate ${ }^{1}$ are among the most commonly occurring congenital impairments (Mossey \& Little 2002) and may affect a child's ability to feed, chew, breathe and hear, as

\footnotetext{
${ }^{1}$ In this paper, the term 'cleft' refers collectively to clefts of the lip, clefts of the palate or clefts of both the lip and the palate.
}

well as cause disturbance to dental, facial, speech and language development (Clinical Standards Advisory Group 1998). Other possible consequences include effects on emotional and social well-being, behavioural and learning difficulties (Hunt et al. 2005). In the UK, a long-term programme of surgery, orthodontic treatment and speech therapy is offered by multidisciplinary teams of specialist clinicians, to address the functional and appearance-related consequences of having a cleft. 
Table 1. Literature search strategy

\begin{tabular}{|c|c|}
\hline \multicolumn{2}{|l|}{ Cleft literature search } \\
\hline Databases searched: & Search strategy (combination of free text terms in title or abstract and \\
\hline British Nursing Index & Subject Headings): \\
\hline CINAHL Plus & Free text terms: \\
\hline EMBASE & (parent* ${ }^{*}$ mother* or father* or family or families) OR (child* or infant) \\
\hline Health and Psychosocial Instruments & OR (adolescen* or young people or young person* or teenage*) OR \\
\hline Maternity and Infant Care & (paediatric* or pediatric*) AND (cleft lip or cleft palate or cleft lip and \\
\hline MEDLINE & palate or craniofacial or cranio-facial) \\
\hline PsychINFO & Subject Headings: \\
\hline Social Sciences Index & British Nursing Index \\
\hline Sociological Abstracts & (CLEFT PALATE) AND (CHILDREN OR PARENTHOOD OR FAMILY) \\
\hline ISI Web of Knowledge & CINAHL Plus \\
\hline Hand searching: & (CLEFT LIP OR CLEFT PALATE) AND (PARENTING OR PARENTS OR CHILD \\
\hline Cleft Palate-Craniofacial Journal & OR ADOLESCENT) \\
\hline Grey literature: & EMBASE \\
\hline Unpublished papers, voluntary sector reports & (CLEFT LIP OR CLEFT PALATE) AND (CHILD OR PARENT) \\
\hline Limitations: from 1980 to present; human subjects; English language & Maternity and Infant Care \\
\hline $\begin{array}{l}\text { Critical appraisal: All studies appraised for quality using criteria for the } \\
\text { critique of both qualitative research (Popay et al. 1998; Seale et al. 2004) }\end{array}$ & $\begin{array}{l}\text { (CLEFT LIP OR CLEFT PALATE) AND (CHILD HEALTH OR INFANT OR } \\
\text { PARENTS) }\end{array}$ \\
\hline and quantitative research [Greenhalgh 2001; Critical Appraisal Skills & MEDLINE \\
\hline Programme (CASP) 2007] & (CLEFT LIP OR CLEFT PALATE) AND (CHILD OR PARENTS) \\
\hline \multicolumn{2}{|l|}{ Long-term conditions literature search } \\
\hline Databases searched: & Search strategy (free text terms in title or abstract): \\
\hline British Nursing Index & Free text terms: \\
\hline CINAHL Plus & (parent* or mother* or father* or family or families) OR (child* or infant) \\
\hline EMBASE & OR (adolescen* or young people or young person* or teenage*) OR \\
\hline Health and Psychosocial Instruments & (paediatric* or pediatric*) AND (chronic disease or chronic illness) OR \\
\hline Maternity and Infant Care & (long term condition or long-term condition) OR (disab*) OR (congenital) \\
\hline MEDLINE & Limitations: from 1990 to present (because of changes in policy/theoretical \\
\hline PsychINFO & perspectives since 1990s); human subjects; English language \\
\hline \multicolumn{2}{|l|}{ Social Sciences Index } \\
\hline \multicolumn{2}{|l|}{ Sociological Abstracts } \\
\hline ISI Web of Knowledge & \\
\hline
\end{tabular}

Biomedical and psychological perspectives have predominated in cleft research to date (Rumsey \& Harcourt 2005) and have focused mainly on the identification of risk factors and measurement of deficits (Eisermann 2001). Some research has also investigated people's views of service-related issues, although qualitative approaches to gauging in-depth perceptions have so far been relatively rare (Nelson 2009). This paper will present a narrative overview of the literature that examines the experiences of parents caring for a child with a cleft, making comparisons with wider, selected literature from the field of children's long-term conditions and disability. It will draw out key issues to highlight similarities and differences, as well as gaps in knowledge.

\section{Literature search and appraisal}

The literature was searched comprehensively to identify publications that have examined the experiences of parents of chil- dren with clefts and more selectively for articles about parents and long-term conditions including disability. The search strategy is presented in Table 1, while Table 2 presents a summary of the 57 publications found.

\section{Emotional experiences of having a child with a cleft}

Early experiences and needs

Discourses of 'loss', 'mourning' and 'correcting' have been common in research perspectives surrounding the diagnosis of a child with a cleft, informed by the assumptions of earlier theoretical perspectives (Olshansky 1962; Solnit \& Stark 1962; Drotar et al. 1975). Both pre- and post-natally, across countries and cultures, parents' feelings of shock, anger, grief and worry have been documented both in surveys and in qualitative studies (Bradbury \& Hewison 1994; Rey-Bellet \& Hohlfeld 
Table 2. Details of cleft lip and palate studies included in the review

\begin{tabular}{|c|c|c|c|c|}
\hline Author and year & Focus of the study & Methods & $\begin{array}{l}\text { Sample } \\
\text { size } \\
\text { (parents) }\end{array}$ & Strengths and limitations \\
\hline \multicolumn{5}{|l|}{ Mixed-methods studies } \\
\hline Benson et al. 1991 & $\begin{array}{l}\text { Coping/adaptation } \\
\text { (social support) } \\
\text { USA }\end{array}$ & $\begin{array}{l}\text { Questionnaires } \\
\text { Semi-structured interviews }\end{array}$ & 72 & $\begin{array}{l}\text { Matched comparison child group; validated measure (Social } \\
\text { Support Questionnaire - Revised) } \\
\text { Response rate/parent characteristics missing; fathers } \\
\text { under-represented }\end{array}$ \\
\hline $\begin{array}{l}\text { Bradbury and Hewison } \\
\quad 1994\end{array}$ & $\begin{array}{l}\text { Coping/adaptation } \\
\text { UK }\end{array}$ & $\begin{array}{l}\text { Semi-structured interviews } \\
\text { Questionnaire }\end{array}$ & 59 & $\begin{array}{l}\text { Recruitment details/sample characteristics missing; } \\
\text { qualitative data collection/analysis not fully described }\end{array}$ \\
\hline Cadogan et al. 2009 & $\begin{array}{l}\text { Information } \\
\text { (diagnosis) } \\
\text { UK }\end{array}$ & $\begin{array}{l}\text { Questionnaire incorporating } \\
\text { both closed and open } \\
\text { questions }\end{array}$ & 31 & $\begin{array}{l}100 \% \text { response rate; longitudinal } \\
\text { Small sample; qualitative analysis details missing }\end{array}$ \\
\hline $\begin{array}{l}\text { Cleft Lip and Palate } \\
\text { Association } 2007 \\
\text { Voluntary sector } \\
\text { report }\end{array}$ & $\begin{array}{l}\text { Services (care } \\
\text { provision) } \\
\text { UK }\end{array}$ & $\begin{array}{l}\text { Questionnaire with some } \\
\text { open-ended questions }\end{array}$ & 227 & $\begin{array}{l}40 \% \text { response rate } \\
\text { Sampling strategy/characteristics missing and mainly from } \\
\text { parent support group }\end{array}$ \\
\hline Eisermann 2001 & $\begin{array}{l}\text { Positive outcomes } \\
\text { USA }\end{array}$ & $\begin{array}{l}\text { Questionnaire } \\
\text { Unstructured interviews }\end{array}$ & 11 & $\begin{array}{l}\text { Comparable/contrasting cases addressed } \\
\text { Response rate missing; convenience sampling; sample not } \\
\text { diverse and mainly from support organizations; gender } \\
\text { mix of sample missing }\end{array}$ \\
\hline Martin 1995 & $\begin{array}{l}\text { Information } \\
\text { (diagnosis) } \\
\text { UK }\end{array}$ & Questionnaire & 41 & $\begin{array}{l}\text { Fathers and mothers; } 70 \% \text { response rate } \\
\text { Sample characteristics/instrument details/children's ages } \\
\text { missing; sample from support group only; qualitative } \\
\text { analysis missing }\end{array}$ \\
\hline Nelson et al. 2009 & $\begin{array}{l}\text { Perceptions of } \\
\text { cause } \\
\text { UK }\end{array}$ & $\begin{array}{l}\text { Questionnaire incorporating } \\
\text { open-ended items }\end{array}$ & 42 & $\begin{array}{l}\text { Some validated scales (Hospital Anxiety and Depression } \\
\text { Scale, Perceived Stress Scale) } \\
\text { Framework analysis } \\
21 \% \text { response rate }\end{array}$ \\
\hline Pelchat et al. 2004 & $\begin{array}{l}\text { Coping/adaptation } \\
\text { (support from } \\
\text { services) } \\
\text { Canada }\end{array}$ & $\begin{array}{l}\text { Questionnaire and free } \\
\text { comments to each question }\end{array}$ & 76 & $\begin{array}{l}80 \% \text { response rate } \\
\text { Analysis of qualitative data not described }\end{array}$ \\
\hline Slade et al. 1999 & $\begin{array}{l}\text { Coping/adaptation } \\
\text { UK }\end{array}$ & $\begin{array}{l}\text { Questionnaires } \\
\text { Structured interviews }\end{array}$ & 32 & $\begin{array}{l}\text { 88\% response rate; validated instruments (Symptom } \\
\text { Checklist 90-R, Edinburgh Postnatal Depression Scale, Self } \\
\text { Perception Inventory, Neonatal Perception Inventory, } \\
\text { Impact of Event Scale, Parental Competence Scale); } \\
\text { Iongitudinal } \\
\text { Small sample size; qualitative analysis not fully described }\end{array}$ \\
\hline \multicolumn{5}{|l|}{ Qualitative studies } \\
\hline $\begin{array}{l}\text { Cartwright and Magee } \\
2006 \text { Voluntary } \\
\text { sector report }\end{array}$ & $\begin{array}{l}\text { Information (needs) } \\
\text { UK }\end{array}$ & $\begin{array}{l}\text { Focus groups } \\
\text { One-to-one interviews }\end{array}$ & 3 & $\begin{array}{l}\text { In-depth focus; framework analysis } \\
\text { Response rate missing; sample small and from support } \\
\text { group only }\end{array}$ \\
\hline $\begin{array}{l}\text { Chuacharoen et al. } \\
2009\end{array}$ & $\begin{array}{l}\text { Information (needs) } \\
\text { Thailand }\end{array}$ & Semi-structured interviews & 15 & $\begin{array}{l}\text { Longitudinal; independent interviewer; content analysis } \\
\text { Response rate/recruitment details/sampling strategy missing }\end{array}$ \\
\hline $\begin{array}{l}\text { Farrimond and Morris } \\
2004 \text { Unpublished } \\
\text { undergraduate } \\
\text { dissertation }\end{array}$ & $\begin{array}{l}\text { Information } \\
\text { (diagnosis) } \\
\text { UK }\end{array}$ & Semi-structured interviews & 10 & $\begin{array}{l}\text { In-depth/flexible approach; reflexive stance; interpretive } \\
\text { Phenomenological analysis } \\
\text { Response rate missing }\end{array}$ \\
\hline $\begin{array}{l}\text { Johansson and } \\
\text { Ringsberg } 2004\end{array}$ & $\begin{array}{l}\text { Coping/adaptation } \\
\text { (social support) } \\
\text { Sweden }\end{array}$ & Semi-structured interviews & 30 & $\begin{array}{l}\text { In-depth focus; use of phenomenology } \\
\text { Response rate missing; sample not diverse }\end{array}$ \\
\hline Klein et al. 2006 & $\begin{array}{l}\text { Parenting } \\
\text { USA }\end{array}$ & Semi-structured interviews & 9 & $\begin{array}{l}\text { In-depth focus } \\
\text { Response rate missing; sample from parent support } \\
\text { organization only }\end{array}$ \\
\hline Martin 2005 & $\begin{array}{l}\text { Information } \\
\quad \text { (prenatal } \\
\text { diagnosis) }\end{array}$ & Structured interviews & 10 & $\begin{array}{l}100 \% \text { response rate; mothers and fathers } \\
\text { Ages of children missing; little flexibility in study instrument; } \\
\text { analysis techniques/reflexive stance missing }\end{array}$ \\
\hline
\end{tabular}


Table 2. Continued

\begin{tabular}{|c|c|c|c|c|}
\hline Author and year & Focus of the study & Methods & $\begin{array}{l}\text { Sample } \\
\text { size } \\
\text { (parents) }\end{array}$ & Strengths and limitations \\
\hline Nusbaum et al. 2008 & $\begin{array}{l}\text { Information } \\
\text { (diagnosis) } \\
\text { USA }\end{array}$ & Semi-structured interviews & 20 & $\begin{array}{l}63 \% \text { response rate; in-depth/flexible approach; includes } \\
\text { comparable and contrasting findings; reflexive stance } \\
\text { Sample lacks variation }\end{array}$ \\
\hline Owens 2008 & $\begin{array}{l}\text { Services (feeding } \\
\text { support) } \\
\text { UK }\end{array}$ & Narrative interviews & 20 & $\begin{array}{l}\text { Recruitment/sample details missing; few details of analysis } \\
\text { techniques; no treatment of negative cases }\end{array}$ \\
\hline \multicolumn{5}{|l|}{ Quantitative studies } \\
\hline $\begin{array}{l}\text { Andrews-Casal et al. } \\
1998\end{array}$ & $\begin{array}{l}\text { Coping/adaptation } \\
\text { USA }\end{array}$ & Questionnaires & 61 & $\begin{array}{l}52 \% \text { response rate; some validated instruments (Parenting } \\
\text { Stress Index, Hollingshead Index of Social Position) } \\
\text { Gender mix of sample unclear }\end{array}$ \\
\hline Baker et al. 2009 & $\begin{array}{l}\text { Coping/adaptation } \\
\text { UK }\end{array}$ & Questionnaires & 103 & $\begin{array}{l}\text { Validated study instruments (Coping Response Inventory, } \\
\text { Interpersonal Support Evaluation List-Short Form, } \\
\text { Stress-Related Growth Scale, General Health } \\
\text { Questionnaire, Family Impact Scale) } \\
\text { Response rate unclear; fathers under-represented }\end{array}$ \\
\hline Barden et al. 1989 & $\begin{array}{l}\text { Mother-infant } \\
\text { interaction/ } \\
\text { attachment } \\
\text { USA }\end{array}$ & $\begin{array}{l}\text { Observation } \\
\text { Questionnaires }\end{array}$ & 10 & $\begin{array}{l}\text { Comparison group } \\
\text { Recruitment/response rate details missing; small and diverse } \\
\text { sample; laboratory conditions; cross-sectional }\end{array}$ \\
\hline $\begin{array}{l}\text { Berger and Dalton } \\
\quad 2009\end{array}$ & $\begin{array}{l}\text { Coping/adaptation } \\
\text { UK }\end{array}$ & Questionnaire & 143 & $\begin{array}{l}\text { Reasonable sample size (multi-centre); validated instruments } \\
\text { (General Well-Being Scale, Brief COPE, Satisfaction with } \\
\text { Appearance Questionnaire) } \\
\text { 37\% response rate; unrepresentative sample; fathers } \\
\text { under-represented }\end{array}$ \\
\hline Black et al. 2009 & $\begin{array}{l}\text { Adaptation } \\
\text { Thailand, China, } \\
\text { Colombia }\end{array}$ & Questionnaire & 98 & $\begin{array}{l}\text { Sample size reasonable and representative } \\
\text { Recruitment details/children's ages missing; no fathers }\end{array}$ \\
\hline Broder et al. 1992 & $\begin{array}{l}\text { Services (outcome } \\
\text { of care) } \\
\text { USA }\end{array}$ & Standardized interviews & 495 & $\begin{array}{l}\text { Good sample size } \\
\text { Recruitment/sample details/response rate unclear }\end{array}$ \\
\hline Broder and Trier 1985 & $\begin{array}{l}\text { Information } \\
\text { (diagnosis) } \\
\text { USA }\end{array}$ & Questionnaire & 37 & $46 \%$ response rate; sample small and characteristics missing \\
\hline Byrnes et al. 2003 & $\begin{array}{l}\text { Information } \\
\text { (diagnosis) } \\
\text { USA }\end{array}$ & Questionnaire & 98 & $\begin{array}{l}\text { Reasonable sample size } \\
43 \% \text { response rate; fathers under-represented }\end{array}$ \\
\hline Campis et al. 1995 & $\begin{array}{l}\text { Coping/adaptation } \\
\text { USA }\end{array}$ & Questionnaires & 77 & $\begin{array}{l}\text { 95\% response rate; validated instruments (Child Behavior } \\
\text { Checklist, Beck Depression Inventory, Spielberger Trait } \\
\text { Anxiety Scale, Parenting Stress Index, Social Support } \\
\text { Questionnaire - Revised) } \\
\text { Sample unrepresentative }\end{array}$ \\
\hline Canady et al. 1997 & $\begin{array}{l}\text { Services (continuity } \\
\text { of care) } \\
\text { USA }\end{array}$ & Questionnaire & 96 & $73 \%$ response rate; few sample or study instrument details \\
\hline $\begin{array}{l}\text { Cleft Lip and Palate } \\
\text { Association } 1996 \\
\text { Voluntary sector } \\
\text { report }\end{array}$ & $\begin{array}{l}\text { Services (care } \\
\text { provision) } \\
\text { UK-wide }\end{array}$ & Questionnaire & 102 & $\begin{array}{l}100 \% \text { response rate } \\
\text { Sampling strategy/characteristics missing; sample from } \\
\text { parent support group only }\end{array}$ \\
\hline $\begin{array}{l}\text { Davalbhakta and Hall } \\
2000\end{array}$ & $\begin{array}{l}\text { Information } \\
\text { (diagnosis) } \\
\text { UK }\end{array}$ & Questionnaire & 90 & $\begin{array}{l}78 \% \text { response rate; sample size reasonable } \\
\text { Sample characteristics/instrument details missing }\end{array}$ \\
\hline $\begin{array}{l}\text { Endriga and Speltz } \\
1997\end{array}$ & $\begin{array}{l}\text { Mother-infant } \\
\text { interaction and }\end{array}$ & Observation & 116 & $\begin{array}{l}\text { Matched control group } \\
\text { Response rate missing; cross-sectional; laboratory-based }\end{array}$ \\
\hline
\end{tabular}


Table 2. Continued

\begin{tabular}{|c|c|c|c|c|}
\hline Author and year & Focus of the study & Methods & $\begin{array}{l}\text { Sample } \\
\text { size } \\
\text { (parents) }\end{array}$ & Strengths and limitations \\
\hline $\begin{array}{l}\text { Field and Vega-Lahr } \\
\quad 1984\end{array}$ & $\begin{array}{l}\text { Mother-infant } \\
\text { interaction and } \\
\text { attachment } \\
\text { USA }\end{array}$ & Observation & 24 & $\begin{array}{l}\text { Recruitment/response rate missing; small sample; control } \\
\text { group matched on some variables but not fully described }\end{array}$ \\
\hline $\begin{array}{l}\text { Jeffery and Boorman } \\
2001\end{array}$ & $\begin{array}{l}\text { Services (care } \\
\text { provision) } \\
\text { UK }\end{array}$ & Questionnaire & 341 & $\begin{array}{l}72 \% \text { response rate; good sample size } \\
\text { Sample characteristics missing }\end{array}$ \\
\hline Kramer et al. 2007 & $\begin{array}{l}\text { Quality of life } \\
\text { Germany }\end{array}$ & Questionnaire & 130 & $\begin{array}{l}84 \% \text { response rate; validated instrument (Impact on Family } \\
\text { Scale) } \\
\text { Gender mix of sample unclear }\end{array}$ \\
\hline $\begin{array}{l}\text { Krueckeberg and } \\
\text { Kapp-Simon } 1993\end{array}$ & $\begin{array}{l}\text { Coping adaptation } \\
\text { USA }\end{array}$ & Questionnaires & 52 & $\begin{array}{l}\text { Comparison group; validated instruments (Parenting Stress } \\
\text { Index, Modification of the Block Child Rearing Practices } \\
\text { Report, Social Relationship Scale, Four Factor Index of } \\
\text { Social Status, Social Skills Questionnaire) } \\
\text { Response rate missing; sample relatively small; gender mix } \\
\text { of sample missing }\end{array}$ \\
\hline Locker et al. 2002 & $\begin{array}{l}\text { Quality of life } \\
\text { Canada }\end{array}$ & Questionnaire & 93 & $\begin{array}{l}\text { Validated scale (Family Impact Scale) } \\
\text { Recruitment/response rate and sample characteristics } \\
\text { missing }\end{array}$ \\
\hline Murray et al. 2008 & $\begin{array}{l}\text { Mother-infant } \\
\text { interaction and } \\
\text { attachment } \\
\text { UK }\end{array}$ & $\begin{array}{l}\text { Observation } \\
\text { Questionnaires }\end{array}$ & 190 & $\begin{array}{l}\text { 75\% response rate; control group; home environment; } \\
\text { some validated instruments (Behaviour Screening } \\
\text { Questionnaire, Structured Clinical Interview for DSM } \\
\text { Diagnoses) }\end{array}$ \\
\hline Noar 1991 & $\begin{array}{l}\text { Services (outcome } \\
\text { of care) } \\
\text { UK }\end{array}$ & Questionnaire & 30 & $\begin{array}{l}\text { Instrument piloted } \\
\text { Recruitment/response rate and sample details missing; small } \\
\text { sample }\end{array}$ \\
\hline Noor and Musa 2007 & $\begin{array}{l}\text { Services (care } \\
\text { provision/ } \\
\text { outcome) } \\
\text { Malaysia }\end{array}$ & Standardized interview & 60 & $\begin{array}{l}\text { Validated instrument (Cleft Evaluation Profile) } \\
\text { Recruitment/response rate details missing; gender mix of } \\
\text { sample unclear }\end{array}$ \\
\hline Oliver and Jones 1997 & $\begin{array}{l}\text { Services (feeding } \\
\text { support) } \\
\text { UK }\end{array}$ & Questionnaire & 100 & $\begin{array}{l}64 \% \text { response rate } \\
\text { Children's ages/sample characteristics/study instrument } \\
\text { details missing }\end{array}$ \\
\hline $\begin{array}{l}\text { Pannbacker and } \\
\text { Scheuerle } 1993\end{array}$ & $\begin{array}{l}\text { Decision making } \\
\text { USA }\end{array}$ & Questionnaire & 42 & $\begin{array}{l}56 \% \text { response rate } \\
\text { Small sample; children's ages/sample characteristics/study } \\
\text { instrument details missing }\end{array}$ \\
\hline Pelchat et al. 1999 & $\begin{array}{l}\text { Coping/adaptation } \\
\text { Canada }\end{array}$ & Questionnaires & 74 & $\begin{array}{l}\text { 91\% response rate; matched comparison groups; validated } \\
\text { instruments (Stress Appraisal Measure, Parenting Stress } \\
\text { Index, Emotional Distress Index-Quebec Health and Social } \\
\text { Survey); longitudinal }\end{array}$ \\
\hline Pope et al. 2005 & $\begin{array}{l}\text { Coping/adaptation } \\
\text { USA }\end{array}$ & Questionnaires & 47 & $\begin{array}{l}\text { Longitudinal, validated instruments (Parenting Stress } \\
\text { Index-Short Form, Child Behavior Checklist) } \\
\text { Response rate unclear; sample characteristics and gender } \\
\text { mix unclear }\end{array}$ \\
\hline $\begin{array}{l}\text { Rey-Bellet and } \\
\text { Hohlfeld } 2004\end{array}$ & $\begin{array}{l}\text { Information/ } \\
\text { counselling } \\
\text { Switzerland }\end{array}$ & Questionnaire & 29 & $\begin{array}{l}82 \% \text { response rate } \\
\text { Parents' socio-economic characteristics missing; analysis } \\
\text { details missing; unclear how many fathers participated }\end{array}$ \\
\hline Sank et al. 2003 & $\begin{array}{l}\text { Coping/adaptation } \\
\text { (social support) } \\
\text { USA }\end{array}$ & Questionnaires & 145 & $\begin{array}{l}\text { 98\% response rate; validated instruments (Interpersonal } \\
\text { Support Evaluation List, Beck Depression Inventory) } \\
\text { No fathers }\end{array}$ \\
\hline Semb et al. 2005 & $\begin{array}{l}\text { Services (care } \\
\text { provision/ } \\
\text { outcome) } \\
\text { Denmark, Norway, } \\
\text { UK, Netherlands, } \\
\text { Sweden }\end{array}$ & Questionnaire & 81 & $\begin{array}{l}65 \% \text { response rate; questionnaire piloted; longitudinal } \\
\text { Sample characteristics of parents missing }\end{array}$ \\
\hline
\end{tabular}


Table 2. Continued

\begin{tabular}{|c|c|c|c|c|}
\hline Author and year & Focus of the study & Methods & $\begin{array}{l}\text { Sample } \\
\text { size } \\
\text { (parents) }\end{array}$ & Strengths and limitations \\
\hline Speltz et al. 1990 & $\begin{array}{l}\text { Coping/adaptation } \\
\text { USA }\end{array}$ & $\begin{array}{c}\text { Questionnaires } \\
\text { Observation }\end{array}$ & 55 & $\begin{array}{l}\text { Matched control group; validated instruments (Parenting } \\
\text { Stress Index, General Well-Being Scale, Social Health } \\
\text { Battery, Locke-Wallace Marital Adjustment Scale) } \\
\text { Response rate missing; small sample }\end{array}$ \\
\hline Speltz et al. 1993 & $\begin{array}{l}\text { Coping/adaptation } \\
\text { USA }\end{array}$ & Questionnaires & 33 & $\begin{array}{l}\text { Control group; validated instruments (Dyadic Parent-Child } \\
\text { Interaction Coding System, Nursing Child Assessment } \\
\text { Teaching Scale, General Well-Being Schedule, Social } \\
\text { Network Reciprocity and Dimensionality Assessment Tool, } \\
\text { Dyadic Adjustment Scale, Child Behavior Checklist); } \\
\text { longitudinal } \\
\text { Small sample }\end{array}$ \\
\hline Speltz et al. 1994 & $\begin{array}{l}\text { Mother-infant } \\
\text { interaction and } \\
\text { attachment } \\
\text { USA }\end{array}$ & $\begin{array}{c}\text { Questionnaires } \\
\text { Observation }\end{array}$ & 51 & $\begin{array}{l}100 \% \text { response rate; control group } \\
\text { Clinic conditions; cross-sectional }\end{array}$ \\
\hline Speltz et al. 1997 & $\begin{array}{l}\text { Mother-infant } \\
\text { interaction and } \\
\text { attachment } \\
\text { USA }\end{array}$ & Questionnaires & 115 & $\begin{array}{l}\text { Control group; validated instruments (Mental Health Index, } \\
\text { Parenting Stress Index, Dyadic Adjustment Scale, Family } \\
\text { Environment Scale, Questionnaire on Social Support); } \\
\text { longitudinal design } \\
\text { Response rate missing; laboratory-based }\end{array}$ \\
\hline Strauss et al. 1988 & $\begin{array}{l}\text { Services (outcome } \\
\text { of care) } \\
\text { USA }\end{array}$ & Standardized interviews & 102 & $\begin{array}{l}\text { Study instrument piloted } \\
\text { Recruitment/response rate and parent sample } \\
\text { characteristics missing }\end{array}$ \\
\hline Strauss et al. 1995 & $\begin{array}{l}\text { Information } \\
\quad \text { (diagnosis) } \\
\text { USA }\end{array}$ & Questionnaire & 100 & $\begin{array}{l}76 \% \text { response rate; reasonable sample size; survey } \\
\text { instrument piloted } \\
\text { Fathers under-represented }\end{array}$ \\
\hline Strauss et al. 2007 & $\begin{array}{l}\text { Experiences of } \\
\text { stigmatization } \\
\text { USA }\end{array}$ & Questionnaire & 153 & $\begin{array}{l}\text { Reasonable sample size; response rate missing; convenience } \\
\text { sample; fathers excluded }\end{array}$ \\
\hline Thomas et al. 1997 & $\begin{array}{l}\text { Services (outcome } \\
\text { of care) } \\
\text { UK }\end{array}$ & Questionnaire & 62 & $\begin{array}{l}70 \% \text { response rate } \\
\text { Parent sample characteristics missing }\end{array}$ \\
\hline Turner et al. 1997 & $\begin{array}{l}\text { Services (care } \\
\text { provision/ } \\
\text { outcome) } \\
\text { UK }\end{array}$ & Standardized interview & 130 & $\begin{array}{l}76 \% \text { response rate } \\
\text { Recruitment/parent sample details missing }\end{array}$ \\
\hline $\begin{array}{l}\text { Turner and Milward } \\
1988\end{array}$ & $\begin{array}{l}\text { Services (care } \\
\text { provision) } \\
\text { UK }\end{array}$ & Structured interviews & 60 & $\begin{array}{l}\text { Recruitment/response rate/details of study instrument } \\
\text { missing; gender mix of sample unclear }\end{array}$ \\
\hline Williams et al. 2001 & $\begin{array}{l}\text { Services (care } \\
\text { provision/ } \\
\text { outcome) } \\
\text { UK }\end{array}$ & Questionnaire & 438 & $\begin{array}{l}76 \% \text { response rate; robust sample size; multi-centre } \\
\text { Parent sample characteristics missing }\end{array}$ \\
\hline Young et al. 2001 & $\begin{array}{l}\text { Information } \\
\text { (diagnosis) } \\
\text { USA }\end{array}$ & Questionnaire & 40 & $\begin{array}{l}100 \% \text { response rate } \\
\text { Sample unrepresentative; fathers under-represented }\end{array}$ \\
\hline
\end{tabular}

2004; Martin 2005; Black et al. 2009; Cadogan et al. 2009; Chuacharoen et al. 2009). In-depth qualitative research, however, has been able to reveal a wider range of experience, often highlighting parents' elation at a child's birth, or perceptions of a child's cleft as unremarkable or unique (Eisermann 2001; Farrimond \& Morris 2004; Johansson \& Ringsberg 2004; Klein et al. 2006).
Feelings of parental guilt, self-blame and associated anxiety have also been described (Strauss et al. 1995; Byrnes et al. 2003; Nelson et al. 2009) with recognition that parents may to wish share their feelings and get emotional support from experienced professionals at the time of diagnosis (Martin 1995; Strauss et al. 1995; Byrnes et al. 2003; Johansson \& Ringsberg 2004; 
Rey-Bellet \& Hohlfeld 2004). The quality of both quantitative and qualitative studies in this body of research is variable, however, with half omitting to provide response rates and a quarter to document children's ages. Most exclude fathers and focus on the collection of cross-sectional data alone. In addition, the quantitative studies comprise samples as small as 25 and use few validated measures, while little of the qualitative research fully presents its approach or findings.

Studies of the early developing relationship between parents and children with clefts have been strongly informed by attachment theory (Bowlby 1965) and suggest that infants may be as securely attached to their mothers as those without clefts (Speltz et al. 1990, 1993, 1997; Endriga \& Speltz 1997; Slade et al. 1999), with a potentially less sensitive interplay between the two because of possible disturbances in communication cues (Field \& Vega-Lahr 1984; Barden et al. 1989; Speltz et al. 1990, 1994; Endriga \& Speltz 1997; Murray et al. 2008). Although the majority have used validated instruments, their findings are based on relatively small and diverse samples, comprised of between $n=10$ and $n=55$. Only four took a longitudinal approach to track developments over time, but their groups were inconsistently matched, sometimes including children with associated developmental difficulties as well as a cleft (Speltz et al. 1993, 1997; Murray et al. 2008). Most notably, only one study (Murray et al. 2008), which was also the most robust in terms of sample size at $n=190$, observed mothers and infants in their own homes, the remainder having been conducted in artificial laboratory conditions. Attachment theory has been widely criticized outside the field on the grounds that it takes no account of social or environmental context on the developing parent-child relationship (Knestrict 2002) and reinforces stereotypical maternal roles, attributing responsibility for a child's emotional and social difficulties to women alone (Contratto 2002).

Although feeding difficulties have been reported among parents of infants with clefts in one UK survey $(n=100$; Oliver \& Jones 1997), research to explore parents' emotional experiences of feeding their child has been relatively rare. Only one qualitative study has offered some insight into the emotional impact on mothers of pressure to successfully breastfeed (Owens 2008), but it provides little information on its sampling and recruitment strategy or details of whether any cases might have contrasted with the analysis presented.

\section{Emotional 'strain'}

Several psychological studies based in the USA have focused on the assessment of stress levels among parents caring for children with clefts, investigating outcomes such as anxiety, depression and poor psychological 'adjustment', collectively referred to here as emotional 'strain'. Some studies have found evidence of raised levels of emotional strain among parents in their child's toddlerhood (Speltz et al. 1990, 1993; Pope et al. 2005), but findings generally suggest that by pre-school years, levels are equivalent to those in parents of children without clefts (Krueckeberg \& Kapp-Simon 1993; Campis et al. 1995; Andrews-Casal et al. 1998; Pelchat et al. 1999; Slade et al. 1999; Berger \& Dalton 2009). Most of these studies have used relatively small sample sizes (average $n=58$ ) along with diverse research instruments, making inferences difficult to draw. Further, accounts from parents in their own words are rare and the focus of research has primarily been on the negative experiences associated with caring for a child with a cleft, to the relative exclusion of potentially positive aspects (Eisermann 2001; Baker et al. 2009).

Some studies have suggested that a child's cleft treatment and clinic attendances may impact adversely on families' quality of life (Locker et al. 2002; Baker et al. 2009), and outside the UK a small number of in-depth qualitative studies have highlighted parents' feelings of anxiety about surgery and their perceived need for emotional support through treatment for both themselves and their child (Turner et al. 1997; Eisermann 2001; Johansson \& Ringsberg 2004; Klein et al. 2006). However, as far as is known, no previous studies have aimed to explore the emotional experiences of parents in connection with their child's treatment pathway.

\section{Coping}

Research in the field on parental coping is subsumed in the studies outlined in the preceding section; however, it is important to highlight that the focus of this work has been mainly on the cross-sectional assessment of poor 'adjustment' in deficitoriented ways (Baker et al. 2009) with no longitudinal work to track parental coping as a child becomes older. Contextual factors have largely been excluded in this body of work too, with studies taking little account of issues other than a child's cleft that may be affecting families' lives (Krueckeberg \& KappSimon 1993). The incorporation of 'resilience' models in the investigation of coping in cleft research has been highlighted as a desirable goal (Broder 2001; Kapp-Simon \& Gaither 2009), yet little published research of this kind exists to date. However, influenced by models of resilience and positive coping, a recent British study $(n=103)$, using validated study instruments including the Coping Response Inventory and the Stress Related Growth Scale, investigated coping strategies and 
perceptions of positive outcomes among parents (Baker et al. 2009). The study found a high degree of positive coping and outlook, particularly in parents of children with more extensive clefts.

Studies using mainly qualitative methods have also offered insights into the positive and/or rewarding aspects of caring for a child with a cleft that have been identified by parents themselves. Such rewards include recognition of their own personal strengths, stronger relationships, appreciation of diversity and others' good intentions, tolerance, a sense of community and hope for the future (Bradbury \& Hewison 1994; Eisermann 2001; Klein et al. 2006). Parents have also reported recognizing their child's strengths, such as a determined attitude, perseverance and sociability (Klein et al. 2006). In one study, half of parents reported that they would not remove their child's cleft if given the opportunity (Eisermann 2001).

In terms of coping resources, it has been suggested that because of the stigma potentially associated with having a visible facial difference, parents of children with clefts may lack adequate social support (Benson et al. 1991; Speltz et al. 1993; Pelchat et al. 1999; Sank et al. 2003). Some studies have found low levels of social support among such parents (Benson et al. 1991; Speltz et al. 1993; Campis et al. 1995; Sank et al. 2003), while others find no particular differences between parents of children with and without clefts (Krueckeberg \& Kapp-Simon 1993). Yet others find variation across families, regardless of their child having a cleft (Bradbury \& Hewison 1994; Johansson \& Ringsberg 2004; Baker et al. 2009). However, these studies have not clearly delineated different types of social support and how it might be experienced by parents, distinguishing, for example, the relative impact of formal and informal support.

Investigation of the coping strategies used by parents does not appear to have been a priority in cleft research to date, although a small amount of qualitative work has indirectly revealed some of the strategies which parents may use. These include cognitive or problem-focused strategies such as discussing a child's needs with school staff and thinking of ways to help them establish friendships/handle teasing (Klein et al. 2006). Parents have also reported using emotion-focused strategies such as maintaining a hopeful attitude for the future and a belief in their own competence as parents (Johansson \& Ringsberg 2004; Klein et al. 2006).

\section{Social experiences related to having a child with a cleft}

A smaller body of research has provided insights into parents' social experiences. It is known that children and their families may be 'stigmatized' because of a cleft's effects on appearance and/or function (Goffman 1963; Partridge 1997) and their social experiences characterized by discomfort, anxiety or rejection because of perceived 'differences' (Rumsey \& Harcourt 2005). Research which has been mainly qualitative in nature has revealed the challenges that parents may face in managing others' reactions to their child's cleft. Mothers have described their heightened sensitivity to the reactions of friends and family (Farrimond \& Morris 2004; Johansson \& Ringsberg 2004), the verbal and non-verbal expressions of distaste encountered in public and attempts to conceal their baby or shun social situations in order to avoid feeling 'different' (Bradbury \& Hewison 1994; Johansson \& Ringsberg 2004; Klein et al. 2006).

Parents have also reported in qualitative studies their worries about social issues, including concerns about a child's acceptance by peers, experiences of teasing, finding a life partner and securing employment (Cartwright \& Magee 2006; Klein et al. 2006). Klein and colleagues' in-depth study recorded the distress caused to parents by their child's reported experiences of teasing or bullying at school, or when entering new and unfamiliar settings. This study also uncovered the tension parents experienced in efforts to protect children, while promoting their independence. One survey from the USA $(n=153)$, reported perceived stigmatizing experiences to be prevalent among both mothers and their children (Strauss et al. 2007). In a number of others across countries, between $15 \%$ and $68 \%$ of parents reported feeling their child's self-confidence to have been affected by having a cleft and between $50 \%$ and $68 \%$ felt their child had been teased (Noar 1991; Turner et al. 1997; Semb et al. 2005; Noor \& Musa 2007). Overall, this research has been more balanced in terms of its methods, with quantitative surveys and qualitative studies more equally employed, although fathers' perspectives remain rare.

\section{Experiences of cleft services}

\section{Information and decision making}

The majority of cleft studies have focused on parents' information experiences and needs at the point of diagnosis, with fewer studies addressing these issues across children's age ranges. However, a lack of readily accessible information at diagnosis has been reported (Martin 1995; Cleft Lip and Palate Association 1996; Young et al. 2001), as has parents' need for accurate and balanced information about clefts and their causes (Davalbhakta \& Hall 2000; Young et al. 2001; Nusbaum et al. 2008). Studies have also suggested that most parents prefer to receive 
their information at this time verbally, from specialist practitioners (Strauss et al. 1995; Byrnes et al. 2003).

While the involvement of parents and children in decisions about their care has been encouraged in UK health policy, research about parents' experiences of decision making for their child's cleft treatment is sparse. One small survey from the USA ( $n=42$ ) found that over a third of parents wanted to be more involved in decision making about treatment (Pannbacker \& Scheuerle 1993), and surveys in the UK have also suggested that some parents do not feel involved in decisions and would like more involvement (Turner et al. 1997; Jeffery \& Boorman 2001).

\section{Experiences of service organization, delivery and outcomes}

'Satisfaction' with the organization and delivery of cleft services has been investigated in a number of surveys whose results suggest high ratings among parents both in the UK and elsewhere (Turner et al. 1997; Jeffery \& Boorman 2001; Williams et al. 2001; Semb et al. 2005; Cleft Lip and Palate Association 2007; Kramer et al. 2007; Noor \& Musa 2007). Satisfaction has often been treated rather simplistically in this research, however, as most papers fail to properly define how it is being conceptualized. Some refer to satisfaction with 'care and attention' (Turner et al. 1997; Williams et al. 2001; Noor \& Musa 2007), some to the 'level' of care (Jeffery \& Boorman 2001) and others to the 'manner' of care provided (Semb et al. 2005). Despite the positive ratings of parents reported, areas of concern have also been identified, such as poor access to and co-ordination of services (Martin 1995; Cleft Lip and Palate Association 1996, 2007; Oliver \& Jones 1997). However, these surveys comprise widely differing sample sizes (between $n=30$ and $n=495$ ) and are almost exclusively cross-sectional and apart from the largest study (Williams et al. 2001), from single centres. Further, study instruments in this body of research are diverse and validated measures largely absent.

Research suggests that parents have confidence in cleft clinicians because of their specialism (Johansson \& Ringsberg 2004; Semb et al. 2005; Cleft Lip and Palate Association 2007) and that they have concerns about the lack of knowledge among generic healthcare staff (Turner \& Milward 1988; Cleft Lip and Palate Association 1996; Oliver \& Jones 1997; Johansson \& Ringsberg 2004; Martin 2005; Cartwright \& Magee 2006). Parents have highlighted the importance of having practitioners who communicate well and show sensitivity (Broder \& Trier 1985; Cleft Lip and Palate Association 1996, 2007; Jeffery \& Boorman 2001; Byrnes et al. 2003; Semb et al. 2005; Cartwright \& Magee 2006) and have identified continuity of care from specialist cleft clinicians as especially valuable (Cleft Lip and Palate Association 1996; Canady et al. 1997).

Some literature has also focused on parents' satisfaction with the outcomes of their children's cleft treatment, using the key variables of facial appearance, function and psychosocial wellbeing. These studies too have commonly reported high ratings of satisfaction with treatment (Strauss et al. 1988; Noar 1991; Broder et al. 1992; Thomas et al. 1997; Turner et al. 1997; Williams et al. 2001; Pelchat et al. 2004; Semb et al. 2005; Noor \& Musa 2007; Berger \& Dalton 2009). Some have also found broad agreement between parents and their children (Strauss et al. 1988; Semb et al. 2005; Noor \& Musa 2007), while others have revealed dissimilar views on different variables (Noar 1991; Broder et al. 1992; Thomas et al. 1997; Williams et al. 2001; Berger \& Dalton 2009). On outcomes for psychosocial wellbeing, findings have also been inconsistent, with some suggesting children with clefts to experience low levels of self-confidence and high levels of teasing (Semb et al. 2005; Noor \& Musa 2007). Others report children to be less emotionally and socially affected by their cleft than their parents estimate (Noar 1991), or to experience more social, but fewer emotional effects (Turner et al. 1997). Differences in these findings may be due to the diverse samples and study instruments used, a lack of longitudinal data or multidimensional approaches to researching satisfaction with treatment results in a particularly sensitive context, or differing personal/cultural expectations about the outcomes of care.

\section{Discussion}

This literature review has contributed knowledge about the emotional, social and service-related experiences of parents caring for a child with a cleft, but has highlighted the variable quality of research to date. It has demonstrated that quantitative research in the cleft field has comprised mainly cross-sectional surveys, with relatively small sample sizes focused mainly on mothers. Little qualitative research, either standing alone or as part of mixed-methods designs, has been carried out to investigate parents' perceptions and experiences and varies widely in the extent to which it takes an in-depth approach. Similarities as well as differences are found in the wider literature on children's long-term conditions.

\section{Comparison and contrast with the wider literature}

Parents may encounter particular emotional and social challenges because of a cleft's visible and/or audible effects on 
their child's facial appearance and speech - both of central importance to interpersonal relationships and communication (Rumsey \& Harcourt 2005). None the less, similarities have been found among the parents of children with other long-term conditions in relation to their emotional, social and service-related experiences. Recognition of the potential emotional impact of a child's diagnosis and the need for adequate early emotional and social support is comparable (Grootenhuis \& Last 1997; Sloper 1999; Case 2000; Piggot et al. 2002; Trulsson \& Klingberg 2003; Barr \& McConkey 2007). Parental experiences of social stigma are also reflected in the long-term conditions literature, as is the tension parents may experience between protecting children while fostering their independence (Ray 2003; Rehm \& Bradley 2005; Duguid et al. 2007; Lassetter et al. 2007). Also found are parents' concerns about accessible, well-coordinated services for children (Mitchell \& Sloper 2001; Watson et al. 2002; Law et al. 2003; Beecham et al. 2007) and needs for information (Mitchell \& Sloper 2002; Lawoko 2007). A need for knowledgeable, sensitive practitioners with good communication skills is also reflected here (Davies et al. 2003; Farrant \& Watson 2004; Hallstrom \& Elander 2007), as is the value placed on long-term relationships between families and practitioners (Trulsson \& Klingberg 2003; Lalor et al. 2007). Finally, in common with the cleft literature, high levels of parent satisfaction with treatment outcome are reported in studies of children's surgery (Bridwell et al. 1999; Smith et al. 2006) with similar inconsistencies of opinion between parents and children (Bridwell et al. 1999; Pratt et al. 2002; Rinella et al. 2004; Smith et al. 2006).

Marked differences can be found in the children's long-term conditions literature, however, in terms of both research approaches and focus, particularly in relation to the emotional and service-related aspects of parents' experiences. This literature draws on broader perspectives from sociology, social policy, nursing and health services research, more commonly recognizing the value of both quantitative and qualitative methods to study parents' experiences, often in integrated ways (Lassetter et al. 2007). Observation of naturally occurring interactions between parents and their children in everyday life and interviews to explore both mothers' and fathers' perceptions of the evolving nature of relationships over time are found (Anderson 1981; Lauritzen 1997; Kirk et al. 2005; Santos \& McCollum 2007). The importance of the role of expectations and the need for multiple approaches to investigating parents' satisfaction with services, including in-depth qualitative studies, has also been emphasized here (Callery \& Luker 1996; Smith et al. 2006; Green et al. 2008).

The variation in parents' reactions has been more widely acknowledged outside the cleft field in relation to diagnosis
(Quine \& Pahl 1987; Lane Tanner et al. 1998; Case 2000; Vehkakoski 2007; Bainbridge 2009), and the ambiguity of parents' feelings has been more evenly described (Larson 1998; Kearney \& Griffen 2001; Nelson 2002; Carnevale et al. 2006). The ability of parents to cope and adapt is highlighted in the wider literature, informed by a change in perspective in the 1990s from pathologizing approaches to 'ecological' and 'resilience' models (McCubbin \& McCubbin 1993; Beresford 1994; Wallander \& Varni 1995; Sloper 1999; Rolland \& Walsh 2006). Conceptual frameworks have documented that parents caring for disabled children through treatment may use a wide range of coping strategies, both problem- and emotion-focused (Burr \& Klein 1994; Graungaard \& Skov 2006), and the rewards of caring have also been more widely recognized, with evidence of parents' personal satisfaction and growth (Gregory 1994; Kearney \& Griffen 2001; Nelson 2002; Barnett et al. 2006; King et al. 2006; Lassetter et al. 2007). Although rarely seen in the cleft literature, the emotional impact on parents of children's surgery has been a focus of research in the wider literature (Sobo 2005; Amin et al. 2006; Ben-Amitay et al. 2006; Joseph et al. 2007; MacLaren \& Kain 2008), and parents' views of their children's treatment outcomes as often uncertain have also been brought to light (Lane Tanner et al. 1998; Kearney \& Griffen 2001; Brinchmann et al. 2002; Vehkakoski 2007).

In contrast to cleft research, the wider literature draws heavily on the notion of flexible, holistic services to support families in different ways according to their needs as they move through treatment (McConachie 1994; King et al. 1997; Mitchell \& Sloper 2001; Watson et al. 2002). Theories of 'respectful' or 'family-centred' care have long underpinned research on quality in family services in the wider children's literature (Mittler 1994; Mitchell \& Sloper 2001; Trulsson \& Klingberg 2003) but are relatively rare in the cleft literature so far. Additionally, theoretical perspectives about family involvement in decision making for treatment comprising ideas of 'partnership' between parents and practitioners (Coyne 1997; King et al. 1997; Piggot et al. 2002; Coyne \& Cowley 2007) and family 'empowerment' (Mittler 1994; Mitchell \& Sloper 2001) are central to the wider literature, but absent in cleft research. A substantial body of work in the wider children's literature has also investigated the experiences and preferences of parents about involvement in decision making about their child's care, using a range of research methods (Ellis \& Leventhal 1993; Pyke-Grimm et al. 1999; Brinchmann et al. 2002; Hallstrom et al. 2002; Hallstrom \& Elander 2004; Knopf et al. 2008). This research suggests that preferences cannot be predicted on the basis of demographics alone, but depend on 
the context and nature of particular decisions (Knopf et al. 2008).

\section{Conclusions}

This review is the first to bring together evidence from both quantitative and qualitative research about the experiences of parents caring for a child with a cleft and demonstrates the variable quality of research to date. It highlights that despite a substantial literature, little research has so far examined parents' perspectives in-depth, with a narrow emphasis on cross-sectional, deficit-orientated psychological approaches focused mainly on mothers. Several gaps have been identified, including the lack of research to examine parents' experiences and needs at different stages of their children's lives, as they move through cleft treatment. Above all, research is needed to investigate how both mothers and fathers might experience their child's long-term and complex treatment journey as children become older and to elicit their views about decision making for cleft treatments, particularly elective surgeries.

\section{Key messages}

- This review synthesizes evidence from both quantitative and qualitative research about the experiences of parents caring for a child with a cleft.

- The quality of research on this topic to date has been variable.

- There has been a narrow emphasis on cross-sectional, deficit-orientated psychological approaches focused mainly on mothers.

- Despite a substantial literature, little qualitative research has examined parents' perspectives in-depth across children's ages.

- There has been a lack of research to examine in particular the experiences of mothers and fathers along their child's long-term and complex treatment journey including their views about decision making for cleft treatments.

\section{Acknowledgements}

The authors would like to acknowledge doctoral training funding from the Medical Research Council, UK (Grant No. 05-01377).

\section{References}

Amin, M. S., Harrison, R. L. \& Weinstein, P. (2006) A qualitative look at parents' experience of their child's dental general anaesthesia. International Journal of Paediatric Dentistry, 16, 309-319.

Anderson, J. (1981) The social construction of illness experience: families with a chronically ill child. Journal of Advanced Nursing, 6, 427-434.

Andrews-Casal, M., Johnston, D., Fletcher, J., Mulliken, J. B., Stal, S. \& Hecht, J. T. (1998) Cleft lip with or without cleft palate: effect of family history on reproductive planning, surgical timing and parental stress. Cleft Palate Craniofacial Journal, 35, 52-57.

Bainbridge, L. (2009) Not quite perfect! Diagnosis of a minor congenital abnormality during examination of the newborn. Infant, 5, 28-31.

Baker, S. R., Owens, J., Stern, M. \& Willmot, D. (2009) Coping strategies and social support in the family impact of cleft lip and palate and parents' adjustment and psychological distress. The Cleft Palate-Craniofacial Journal, 46, 229-236.

Barden, R. C., Ford, M. E., Jensen, A. G., Rogers-Salyer, M. \& Salyer, K. E. (1989) Effects of craniofacial deformity in infancy on the quality of mother-infant interactions. Child Development, 60, 819-824.

Barnett, D., Clements, M., Kaplan-Estrin, M., McCaskill, J., Hunt, K. H., Butler, C. M., Schram, J. L. \& Janisse, H. C. (2006) Maternal resolution of child diagnosis: stability and relations with child attachment across the toddler to preschooler transition. Journal of Family Psychology, 20, 100-107.

Barr, O. \& McConkey, R. (2007) A different type of appointment: the experiences of parents who have children with intellectual disabilities. Journal of Research in Nursing, 12, 637-652.

Beecham, J., Sloper, P., Greco, V. \& Webb, R. (2007) The costs of key worker support for disabled children and their families. Child: Care, Health and Development, 33, 611-618.

Ben-Amitay, G., Kosov, I., Reiss, A., Toren, P., Yoran-Hegesh, R., Kotler, M. \& Mozes, T. (2006) Is elective surgery traumatic for children and parents? Journal of Paediatrics and Child Health, 42, 618-624.

Benson, B. A., Gross, A. M., Messer, S. C., Kellum, G. \& Passmore, L. A. (1991) Social support networks among families of children with craniofacial anomalies. Health Psychology, 10, 252 258.

Beresford, B. A. (1994) Resources and strategies: how parents cope with the care of a disabled child. Journal of Child Psychology and Psychiatry, 35, 171-209.

Berger, Z. E. \& Dalton, L. J. (2009) Coping with a cleft: psychosocial adjustment of adolescents with a cleft lip and palate and their parents. The Cleft Palate-Craniofacial Journal, 46, 435-443.

Black, J. D., Girotto, J. A., Chapman, K. \& Oppenheimer, A. J. (2009) When my child was born: cross-cultural reactions to the birth of a child with cleft lip and/or palate. The Cleft Palate-Craniofacial Journal, 46, 545-548.

Bowlby, J. (1965) Child Care and the Growth of Love. Penguin, Harmondsworth, UK. 
Bradbury, E. T. \& Hewison, J. (1994) Early parental adjustment to visible congenital disfigurement. Child: Care, Health and Development, 20, 251-266.

Bridwell, K. H., Baldus, C., Iffrig, T., Lenke, L. \& Blanke, K. (1999) Process measures and patient/parent evaluation of surgical management of spinal deformities in patients with progressive flaccid neuromuscular scoliosis (Duchenne's muscular dystrophy and spinal muscular atrophy). Spine, 24, 1300-1309.

Brinchmann, B. S., Forde, R. \& Nortvedt, P. (2002) What matters to the parents? A qualitative study of parents' experiences with life-death decisions concerning their premature infants. Nursing Ethics, 9, 388-404.

Broder, H. (2001) Using psychosocial assessment and therapeutic strategies to enhance well-being. The Cleft Palate-Craniofacial Journal, 38, 248-254.

Broder, H. \& Trier, W. C. (1985) Effectiveness of genetic counseling for families with craniofacial anomalies. The Cleft Palate Journal, 22, 157-162.

Broder, H. L., Smith, F. B. \& Strauss, R. P. (1992) Habilitation of patients with clefts: parent and child ratings of satisfaction with appearance and speech. The Cleft Palate-Craniofacial Journal, 29, 262-267.

Burr, W. R. \& Klein, S. R. (1994) Re-Examining Family Stress. SAGE Publications, London, UK.

Byrnes, A. L., Berk, N. W., Cooper, M. E. \& Marazita, M. L. (2003) Parental evaluation of informing interviews for cleft lip and/or palate. Pediatrics, 112, 308-313.

Cadogan, J., Marsh, C. \& Winter, R. (2009) Parents' views of 4D ultrasound scans following diagnosis of cleft condition. British Journal of Midwifery, 17, 374-380.

Callery, P. \& Luker, K. (1996) The use of qualitative methods in the study of parents' experiences of care on a children's surgical ward. Journal of Advanced Nursing, 23, 338-345.

Campis, L., DeMaso, D. R. \& Twente, A. W. (1995) The role of maternal factors in the adaptation of children with craniofacial disfigurement. Cleft Palate Craniofacial Journal, 32, 55-61.

Canady, J. W., Means, M. E., Wayne, I., Thompson, S. A. \& Richman, L. C. (1997) Continuity of care: university of Iowa cleft lip/palate interdisciplinary team. The Cleft Palate-Craniofacial Journal, 34, 443-446.

Carnevale, F. A., Alexander, E., Davis, M., Rennick, J. \& Troini, R. (2006) Daily living with distress and enrichment: the moral experience of families with ventilator-assisted children at home. Pediatrics, 117, 48-60.

Cartwright, J. \& Magee, H. (2006) The Views and Experiences of Patients Living with Disfiguring Conditions and Health Professionals Involved in Their Care. Report of a Qualitative Study. Healing Foundation, London, UK.

Case, S. (2000) Refocusing on the parent: what are the social issues of concern for the parents of disabled children? Disability \& Society, 15, 271-292.

Chuacharoen, R., Ritthagol, W., Hunsrisakhun, J. \& Nilmanat, K. (2009) Felt needs of parents who have a 0- to 3-month-old with a cleft lip and palate. The Cleft Palate-Craniofacial Journal, 46, 252-257.

Cleft Lip and Palate Association (1996) Review of current treatment for young children with cleft lip and palate. Available at: http:// www.clapa.com (accessed from September 2006).

Cleft Lip and Palate Association (2007) Regionalisation of cleft lip and palate services: has it worked? A report on users' perspectives of cleft care. Available at: http://www.clapa.com (accessed from June 2008).

Clinical Standards Advisory Group (1998) Cleft Lip and/or Palate. Report of a CSAG Committee. The Stationery Office, London, UK. Contratto, S. (2002) A feminist critique of attachment theory and evolutionary psychology. In: Rethinking Mental Health and Disorder: Feminist Perspectives (eds M. B. Ballou \& L. S. Brown), pp. 29-47. Guildford Press, New York, NY, USA.

Coyne, I. (1997) Chronic illness: the importance of support for families caring for a child with cystic fibrosis. Journal of Clinical Nursing, 6, 121-129.

Coyne, I. \& Cowley, S. (2007) Challenging the philosophy of partnership with parents: a grounded theory study. International Journal of Nursing Studies, 44, 893-904.

Critical Appraisal Skills Programme (CASP). (2007) Solutions for Public Health, NHS, UK. Available at: http://www.sph.nhs.uk/ what-we-do/public-health-workforce/resources/critical-appraisalsskills-programme (accessed from March 2011).

Davalbhakta, A. \& Hall, P. N. (2000) The impact of antenatal diagnosis on the effectiveness and timing of counselling for cleft lip and palate. British Journal of Plastic Surgery, 53, 298-301.

Davies, R., Davis, B. \& Sibert, J. (2003) Parents' stories of sensitive and insensitive care by paediatricians in the time leading up to and including diagnostic disclosure of a life-limiting condition in their child. Child: Care, Health and Development, 29, 77-82.

Drotar, D., Baskiewicz, A., Irving, B., Kennell, J. \& Klaus, M. (1975)

The adaptation of parents to the birth of an infant with a congenital malformation: a hypothetical model. Pediatrics, 56, 710-717.

Duguid, A., Morrison, S., Robertson, A., Chalmers, J., Youngson, G. \& Ahmed, S. F. (2007) The psychological impact of genital anomalies on the parents of affected children. Acta Paediatrica, 96, 348-352.

Eisermann, W. (2001) Unique outcomes and positive contributions associated with facial difference: expanding research and practice. The Cleft Palate-Craniofacial Journal, 38, 236-244.

Ellis, R. \& Leventhal, B. (1993) Information needs and decision making preferences of children with cancer. Psycho-Oncology, 2, 277-284.

Endriga, M. C. \& Speltz, M. L. (1997) Face-to-face interaction between infants with orofacial clefts and their mothers. Journal of Pediatric Psychology, 22, 439-453.

Farrant, B. \& Watson, P. (2004) Health care delivery: perspectives of young people with chronic illness and their parents. Journal of Paediatrics and Child Health, 40, 175-179.

Farrimond, J. \& Morris, M. (2004) Knowing or not knowing before birth: parents' experiences of having a baby with a cleft lip, with or 
without cleft palate. Unpublished BSc Dissertation. University of the West of England, Bristol, UK.

Field, T. M. \& Vega-Lahr, N. (1984) Early interactions between infants with cranio-facial anomalies and their mothers. Infant Behavior \& Development, 7, 527-530.

Goffman, E. (1963) Stigma: Notes on the Management of Spoiled Identity. Prentice-Hall, Englewood Cliffs, NJ, USA.

Graungaard, A. H. \& Skov, L. (2006) Why do we need a diagnosis? A qualitative study of parents' experiences, coping and needs when the newborn child is severely disabled. Child: Care, Health and Development, 33, 296-307.

Green, J., Statham, H. \& Solomou, W. (2008) Working paper. Assessing satisfaction: insights from a multi-methods study. Real Life Methods, Sociology, University of Manchester, Manchester, UK.

Greenhalgh, T. (2001) How to Read a Paper: The Basics of Evidence Based Medicine. BMJ Books, London, UK.

Gregory, S. (1994) Challenging motherhood: mothers and their deaf children. In: Motherhood: Meanings, Practices and Ideologies. London (eds A. Phoenix, A. Woollett \& E. Lloyd), pp. 123-142. SAGE Publications, London, UK; Thousand Oaks, CA, USA; New Delhi, India.

Grootenhuis, M. A. \& Last, B. F. (1997) Adjustment and coping by parents of children with cancer: a review of the literature. Support Care Cancer, 5, 466-484.

Hallstrom, I. \& Elander, G. (2004) Decision-making during hospitalization: parents' and children's involvement. Journal of Clinical Nursing, 13, 367-375.

Hallstrom, I. \& Elander, G. (2007) Families' needs when a child is long-term ill: a literature review with reference to nursing research. International Journal of Nursing Practice, 13, 193-200.

Hallstrom, I., Runeson, I. \& Elander, G. (2002) An observational study of the level at which parents participate in decisions during their child's hospitalization. Nursing Ethics, 9, 202214.

Hunt, O., Burden, D., Hepper, P. \& Johnston, C. (2005) The psychosocial effects of cleft lip and palate: a systematic review. European Journal of Orthodontics, 27, 274-285.

Jeffery, S. L. \& Boorman, J. G. (2001) Patient satisfaction with cleft lip and palate services in a regional centre. British Journal of Plastic Surgery, 54, 189-191.

Johansson, B. \& Ringsberg, K. C. (2004) Parents' experiences of having a child with cleft lip and palate. Journal of Advanced Nursing, 47, 165-173.

Joseph, R. A., Mackley, A. B., Davis, C. G., Spear, M. L. \& Locke, R. G. (2007) Stress in fathers of surgical neonatal intensive care unit babies. Advances in Neonatal Care, 7, 321-325.

Kapp-Simon, K. A. \& Gaither, R. (2009) Psychological and behavioral aspects of clefting. In: Comprehensive Cleft Care (eds J. E. Losee \& R. E. Kirschner), pp. 1001-1010. McGraw Hill, New York, NY, USA.

Kearney, P. M. \& Griffen, T. (2001) Between joy and sorrow: being a parent of a child with a developmental disability. Journal of Advanced Nursing, 34, 582-592.
King, G., Rosenbaum, P. L. \& King, S. (1997) Evaluating family-centered service using a measure of parents' perceptions. Child: Care, Health and Development, 23, 47-62.

King, G. A., Zwaigenbaum, L., King, S., Baxter, D., Rosenbaum, P. \& Bates, A. (2006) A qualitative investigation of changes in the belief systems of families of children with autism or down syndrome. Child: Care, Health and Development, 32, 353-369.

Kirk, S., Glendinning, C. \& Callery, P. (2005) Parent or nurse? The experience of being the parent of a technology-dependent child. Journal of Advanced Nursing, 51, 456-464.

Klein, T., Pope, A. W., Getahun, E. \& Thompson, J. (2006) Mothers' reflections on raising a child with a craniofacial anomaly. The Cleft Palate-Craniofacial Journal, 43, 590-597.

Knestrict, T. D. (2002) A post-modern critique of attachment theory: moving towards a socially just ecological framework. Dissertation Abstracts International: Section B: The Sciences and Engineering, 63, 2621.

Knopf, J. M., Hornung, R. W., Slap, G. B., DeVellis, R. F. \& Britto, M. T. (2008) Views of treatment decision making from adolescents with chronic illnesses and their parents: a pilot study. Health Expectations, 11, 343-354.

Kramer, F. J., Baethge, C., Sinikovic, B. \& Schliephake, H. (2007) An analysis of quality of life in 130 families having small children with cleft lip/palate using the impact on family scale. International Journal of Oral and Maxillofacial Surgery, 36, 1146-1152.

Krueckeberg, S. M. \& Kapp-Simon, K. A. (1993) Effect of parental factors on social skills of preschool children with craniofacial anomalies. The Cleft Palate-Craniofacial Journal, 30, 490-496.

Lalor, J. G., Devane, D. \& Begley, C. M. (2007) Unexpected diagnosis of fetal abnormality: women's encounters with caregivers. Birth, $34,80-88$.

Lane Tanner, J., Dechert, M. P. \& Frieden, I. J. (1998) Growing up with a facial hemangioma: parent and child coping and adaptation. Pediatrics, 101, 446-452.

Larson, E. (1998) Reframing the meaning of disability to families: the embrace of paradox. Social Science \& Medicine, 47, 865-875.

Lassetter, J. H., Mandleco, B. L. \& Olsen Roper, S. (2007) Family photographs: expressions of parents raising children with disabilities. Qualitative Health Research, 17, 456-467.

Lauritzen, S. O. (1997) Notions of child health: mothers' accounts of health in their young babies. Sociology of Health $\&$ Illness, 19, 436-456.

Law, M., Hanna, S., King, G., Hurley, P., King, S., Kertoy, M. \& Rosenbaum, P. (2003) Factors affecting family-centred service delivery for children with disabilities. Child: Care, Health and Development, 29, 357-366.

Lawoko, S. (2007) Factors influencing satisfaction and well-being among parents of congenital heart disease children: development of a conceptual model based on the literature review. Scandinavian Journal of Caring Sciences, 21, 106-117.

Locker, D., Jokovic, A., Stephens, M., Kenny, D. T., Tompson, B. \& Guyatt, G. (2002) Family impact of child oral and oro-facial conditions. Community Dentistry and Oral Epidemiology, 30, 438-448. 
MacLaren, J. \& Kain, Z. N. (2008) A comparison of preoperative anxiety in female patients with mothers of children undergoing surgery. International Anesthesia Research Society, 106, 810-813.

Martin, V. (1995) Helping parents cope. Nursing Times, 91, 38-40.

Martin, V. (2005) Prenatal cleft lip and palate parent programme phase 1. British Journal of Midwifery, 13, 90-95.

McConachie, H. (1994) Implications of a model of stress and coping for services to families of young disabled children. Child: Care, Health and Development, 20, 37-46.

McCubbin, M. A. \& McCubbin, H. I. (1993) Family coping with health crisis: the resiliency model of family stress, adjustment and adaptation. In: Families, Health and Illness (eds C. Danielson, B. Hamel-Bissell \& P. Winstead-Fry), pp. 153-177. Mosby, St Louis, MO, USA.

Mitchell, W. \& Sloper, P. (2001) Quality in services for disabled children and their families: what can theory, policy and research on children's and parents' views tell us? Children \& Society, 15, 237-252.

Mitchell, W. \& Sloper, P. (2002) Information that informs rather than alienates families with disabled children: developing a model of good practice. Health \& Social Care in the Community, 10, 74-81.

Mittler, H. (1994) International initiatives in support of families with a member with learning disabilities. In: Innovations in Family Support for People with Learning Disabilities (eds P. Mittler \& H. Mittler), pp. 15-31. Lisieux Hall, Chorley, UK.

Mossey, P. A. \& Little, J. (2002) Epidemiology of oral clefts: an international perspective. In: Cleft Lip and Palate: From Origin to Treatment (ed. D. F. Wyszynski), pp. 127-158. Oxford University Press, New York, NY, USA.

Murray, L., Hentges, F., Hill, J., Karpf, J., Mistry, B., Kreutz, M., Woodall, P., Moss, T., Goodacre, T. \& the Cleft Lip and Palate Study Team (2008) The effect of cleft lip and palate and the timing of lip repair on mother-infant interactions and infant development. Journal of Child Psychology and Psychiatry, 49, 115-123.

Nelson, A. M. (2002) A metasynthesis: mothering other-than-normal children. Qualitative Health Research, 12, 515-530.

Nelson, P. A. (2009) Qualitative approaches in craniofacial research. The Cleft Palate-Craniofacial Journal, 46, 245-251.

Nelson, J., O'Leary, C. \& Weinman, J. (2009) Causal attributions in parents of babies with a cleft lip and/or palate and their associations with psychological well-being. Cleft Palate-Craniofacial Journal, 46, 425-434.

Noar, J. H. (1991) Questionnaire survey of attitudes and concerns of patients with cleft lip and palate and their parents. The Cleft Palate-Craniofacial Journal, 28, 279-284.

Noor, S. N. F. M. \& Musa, S. (2007) Assessment of patients' level of satisfaction with cleft treatment using the cleft evaluation profile. The Cleft Palate-Craniofacial Journal, 44, 292-303.

Nusbaum, R., Grubs, R., Losee, J. E., Weidman, C., Ford, M. D. \& Marazita, M. L. (2008) A qualitative description of receiving a diagnosis of clefting in the prenatal or postnatal period. Journal of Genetic Counseling, 17, 336-350.

Oliver, R. G. \& Jones, G. (1997) Neonatal feeding of infants born with cleft lip and/or palate: parental perceptions of their experiences in South Wales. The Cleft Palate-Craniofacial Journal, 34, 527-530.

Olshansky, S. (1962) Chronic sorrow: a response to having a mentally defective child. Social Casework, 43, 190-193.

Owens, J. (2008) Parents' experiences of feeding a baby with cleft lip and palate. British Journal of Midwifery, 16, 778-784.

Pannbacker, M. \& Scheuerle, J. (1993) Parents' attitudes toward family involvement in cleft palate treatment. The Cleft Palate-Craniofacial Journal, 30, 87-89.

Partridge, J. (1997) The experience of being visibly different. Introduction to Section One. In: Visibly Different. Coping with Disfigurement (eds R. Lansdown, N. Rumsey, E. Bradbury, T. Carr \& J. Partridge), pp. 3-9. Butterworth Heinemann, Oxford, UK. Pelchat, D., Bisson, J., Ricard, N., Perreault, M. \& Bouchard, J.-M. (1999) Longitudinal effects of an early family intervention programme on the adaptation of parents of children with a disability. International Journal of Nursing Studies, 36, 465-477.

Pelchat, D., Lefebvre, H., Proulx, M. \& Reidy, M. (2004) Parental satisfaction with an early family intervention program. The Journal of Perinatal \& Neonatal Nursing, 18, 128-144.

Piggot, J., Paterson, J. \& Hocking, C. (2002) Participation in home therapy programs for children with cerebral palsy: a compelling challenge. Qualitative Health Research, 12, 1112-1129.

Popay, J., Rogers, A. \& Williams, G. (1998) Rationale and standards for the systematic review of qualitative literature in health services research. Qualitative Health Research, 8, 341-351.

Pope, A., Tillman, K. \& Snyder, H. T. (2005) Parenting stress in infancy and psychosocial adjustment in toddlerhood: a longitudinal study of children with craniofacial anomalies. The Cleft Palate-Craniofacial Journal, 42, 556-559.

Pratt, R., Burwell, G., Cole, A. \& Webb, J. (2002) Patient and parental perception of adolescent idiopathic scoliosis before and after surgery in comparison with surface and radiographic measurements. Spine, 27, 1543-1550.

Pyke-Grimm, K. A., Degner, L. F., Small, A. \& Mueller, B. (1999) Preferences for participation in treatment decision making and information needs of parents of children with cancer: a pilot study. Journal of Pediatric Oncology Nursing, 16, 13-24.

Quine, L. \& Pahl, J. (1987) First diagnosis of severe handicap: a study of parental reactions. Developmental Medicine and Child Neurology, 29, 232-242.

Ray, L. D. (2003) The social and political conditions that shape special-needs parenting. Journal of Family Nursing, 9, 281-304.

Rehm, R. S. \& Bradley, J. F. (2005) Normalization in families raising a child who is medically fragile/technology dependent and developmentally delayed. Qualitative Health Research, 15, 807-820.

Rey-Bellet, C. \& Hohlfeld, J. (2004) Prenatal diagnosis of facial clefts: evaluation of a specialised counselling. Swiss Medical Weekly, 134, 640-644.

Rinella, A., Lenke, L., Peelle, M., Edwards, C., Bridwell, K. H. \& Sides, B. (2004) Comparison of SRS questionnaire results submitted by both parents and patients in the operative treatment of idiopathic scoliosis. Spine, 29, 303-310. 
Rolland, J. S. \& Walsh, F. (2006) Facilitating family resilience with childhood illness and disability. Current Opinion in Pediatrics, 18, 527-538.

Rumsey, N. \& Harcourt, D. (2005) The Psychology of Appearance. Open University Press, Maidenhead, UK.

Sank, J. R., Berk, N. W., Cooper, M. E. \& Marazita, M. L. (2003) Perceived social support of mothers of children with clefts. The Cleft Palate-Craniofacial Journal, 40, 165-171.

Santos, R. M. \& McCollum, J. A. (2007) Perspectives of parent-child interaction in Filipino mothers of very young children with and without disabilities. Journal of Early Intervention, 29, 243-261.

Seale, C., Gobo, G., Gubrium, J. F. \& Silverman, D. (2004) Introduction: inside qualitative research. In Qualitative Research Practice (eds C. Seale, G. Gobo, J. F. Gubrium \& D. Silverman), pp. 1-12. SAGE Publications, London, UK.

Semb, G., Brattstrom, V., Molsted, K., Prahl-Andersen, B., Zuurbier, P., Rumsey, N. \& Shaw, W. C. (2005) The Eurocleft study: intercenter study of treatment outcome in patients with complete cleft lip and palate. Part 4: relationship among treatment outcome, patient/parent satisfaction and the burden of care. The Cleft Palate-Craniofacial Journal, 42, 83-92.

Slade, P., Emerson, D. J. M. \& Freedlander, E. (1999) A longitudinal comparison of the psychological impact on mothers of neonatal and 3 month repair of cleft lip. British Journal of Plastic Surgery, $52,1-5$.

Sloper, P. (1999) Models of service support for parents of disabled children. What do we know? What do we need to know? Child: Care, Health and Development, 25, 85-99.

Smith, P. L., Donaldson, S., Hedden, D., Alman, B., Howard, A., Stephens, D. \& Wright, J. G. (2006) Parents' and patients' perceptions of postoperative appearance in adolescent idiopathic scoliosis. Spine, 31, 2367-2374.

Sobo, E. (2005) Parents' perceptions of pediatric day surgery risks: unforeseeable complications or avoidable mistakes? Social Science \& Medicine, 60, 2341-2350.

Solnit, A. \& Stark, M. H. (1962) Mourning and the birth of a defective child. The Psychoanalytic Study of the Child, 16, 9-24.

Speltz, M. L., Armsden, G. C. \& Clarren, S. S. (1990) Effects of craniofacial birth defects on maternal functioning postinfancy. Journal of Pediatric Psychology, 15, 177-196.

Speltz, M. L., Morton, K., Goodell, E. W. \& Clarren, S. K. (1993) Psychological functioning of children with craniofacial anomalies and their mothers: follow-up from late infancy to school entry. The Cleft Palate-Craniofacial Journal, 30, 482-489.

Speltz, M. L., Goodell, E. W., Endriga, M. C. \& Clarren, S. K. (1994) Feeding interactions of infants with unrepaired cleft lip and/or palate. Infant Behavior \& Development, 17, 131-139.
Speltz, M. L., Endriga, M. C., Fisher, P. A. \& Mason, C. A. (1997) Early predictors of attachment in infants with cleft lip and/or palate. Child Development, 68, 12-25.

Strauss, R. P., Broder, H. L. \& Helms, R. W. (1988) Perceptions of appearance and speech by adolescent patients with cleft lip and palate and by their parents. The Cleft Palate Journal, 25, 335342.

Strauss, R. P., Sharp, M. C., Lorch, S. C. \& Kachalia, B. (1995) Physicians and the communication of 'bad news': parent experiences of being informed of their child's cleft lip and/or palate. Pediatrics, 96, 82-89.

Strauss, R. P., Ramsey, B. L., Edwards, T. C., Topolski, T. D., Kapp-Simon, K. A., Thomas, C. R., Fenson, C. \& Patrick, D. L. (2007) Stigma experiences in youth with facial differences: a multi-site study of adolescents and their mothers. Orthodontics \& Craniofacial Research, 10, 96-103.

Thomas, P. T., Turner, S. R., Rumsey, N., Dowell, T. \& Sandy, J. R. (1997) Satisfaction with facial appearance among subjects affected by a cleft. The Cleft Palate-Craniofacial Journal, 34, 226-231.

Trulsson, U. \& Klingberg, G. (2003) Living with a child with a severe orofacial handicap: experiences from the perspectives of parents. European Journal of Oral Sciences, 111, 19-25.

Turner, M. M. \& Milward, T. M. (1988) A study to assess the effectiveness of a professional and lay support service for parents of new-born cleft babies. British Journal of Plastic Surgery, 41, 614-618.

Turner, S. R., Thomas, P. W. N., Dowell, T., Rumsey, N. \& Sandy, J. R. (1997) Psychological outcomes amongst cleft patients and their families. British Journal of Plastic Surgery, 50, 1-9.

Vehkakoski, T. M. (2007) Newborns with an impairment: discourses of hospital staff. Qualitative Health Research, 17, 288-299.

Wallander, J. L. \& Varni, J. W. (1995) Appraisal, coping and adjustment in adolescents with a physical disorder. In: Adolescent Health Problems: Behavioural Perspectives (eds J. L. Wallander \& L. J. Siegel), pp. 209-231. Guildford Press, New York, NY, USA.

Watson, D., Townsley, R. \& Abbott, D. (2002) Exploring multi-agency working in services to disabled children with complex healthcare needs and their families. Journal of Clinical Nursing, 11, 367-375.

Williams, A., Bearn, D., Mildinhall, S., Murphy, T., Sell, D., Shaw, W. C., Murray, J. J. \& Sandy, J. R. (2001) Cleft lip and palate care in the United Kingdom - the Clinical Standards Advisory Group (CSAG) Study. Part 2: dentofacial outcomes and patient satisfaction. The Cleft Palate-Craniofacial Journal, 38, 24-29.

Young, J. L., O’Riordan, M., Goldstein, J. A. \& Robin, N. H. (2001) What information do parents of newborns with cleft lip, palate or both want to know? The Cleft Palate-Craniofacial Journal, 38, 55-58. 